\title{
THE EFFECT OF DIFFERENT DIETARY SODIUM LEVELS ON BLOOD ELECTROLYTES, GROWTH PERFORMANCE AND FOOT PAD DERMATITIS INCIDENCE IN TURKEYS*
}

\author{
Karolina Lichtorowicz ${ }^{1}$, Jan Jankowski ${ }^{1}$, \\ Zenon Zduńczyk ${ }^{2}$, Jerzy Juśkiewicz ${ }^{2}$ \\ ${ }^{1}$ Chair of Poultry Science \\ University of Warmia and Mazury in Olsztyn \\ ${ }^{2}$ Institute of Animal Reproduction and Food Research \\ of Polish Academy of Sciences
}

\begin{abstract}
The objective of this study was to determine the effect of different dietary sodium levels on serum macroelement concentrations, growth performance and incidence of foot pad dermatitis (FPD) in female turkeys raised to six weeks of age. The influence of a lowsodium diet (without additional sodium) and diets supplemented with $\mathrm{NaCl}$ to increase sodium content by $0.5,1.0,1.5,2.0$ and $2.5 \mathrm{~g} \mathrm{~kg}^{-1}$ was compared. The dietary electrolyte balance (DEB) was high $\left(242-248 \mathrm{mEq} \mathrm{kg}{ }^{-1}\right)$ due to a high potassium content $\left(11.0 \mathrm{~g} \mathrm{~kg}^{-1}\right)$.

Turkeys fed the low-sodium diet were characterized by significantly lower concentrations of chloride $(p=0.002)$ and phosphorus $(p<0.001)$, and significantly higher magnesium levels $(p<0.001)$, compared with the other groups.

The lowest dietary inclusion of sodium $\left(0.5 \mathrm{~g} \mathrm{~kg}^{-1}\right)$ contributed to a significant increase in the body weights of turkeys at six weeks of age $(p<0.001)$, and it improved feed conversion efficiency $(p<0.001)$ in comparison with the low-sodium diet. No significant differences in body weight and feed conversion ratio followed experimental treatments with higher dietary $\mathrm{NaCl}$ addition. Diets supplemented with different amounts of sodium had no effect on litter moisture content, whereas the incidence of FPD increased significantly following the addition of dietary sodium at $1.0 \mathrm{~g} \mathrm{~kg}^{-1}$ to $2.5 \mathrm{~g} \mathrm{~kg}^{-1}$, compared with the low-sodium diet. The results of our study indicate that moderate sodium supplementation $\left(0.5 \mathrm{~g} \mathrm{~kg}^{-1}\right)$ of a sodium-deficient diet significantly increased the body weights of young
\end{abstract}

mgr inż. Karolina Lichtorowicz, Chair of Poultry Science, University of Warmia and Mazury in Olsztyn, Oczapowskiego 5, 10-718 Olsztyn, Poland, e-mail: karolina.lichtorowicz@uwm.edu.pl

* This study was conducted as part of developmental research project No. N R 12009606. 
turkeys, while it did not increase the incidence of FPD. A further increase in the sodium content of experimental diets did not increase the body weights of birds, and it enhanced the occurrence of FPD which was not related to increased litter wetness.

Key words: sodium, blood minerals, growth performance, turkeys.

\title{
WPŁYW ZRÓŻNICOWANEGO POZIOMU SODU W DIECIE NA POZIOM ELEKTROLITÓW KRWI, WZROST INDYKÓW I WYSTĘPOWANIE ZAPALENIA SKÓRY PODUSZKI STOPY
}

\begin{abstract}
Abstrakt
Celem badań było określenie wpływu różnych poziomów sodu w diecie na zawartość makroelementów w surowicy, wzrost ptaków i występowanie zapalenia skóry stóp (FPD) $\mathrm{u}$ indyczek $\mathrm{w}$ wieku sześciu tygodni życia. Porównano efekty podawania diety niskosodowej (bez dodatkowego źródła sodu) i diet z dodatkiem NaCl w ilości 0,$5 ; 1,0 ; 1,5 ; 2.0$ i $2,5 \mathrm{~g} \mathrm{~kg}^{-1}$. Ze względu na wysoka zawartość potasu w dietach $\left(11,0 \mathrm{~g} \mathrm{~kg}^{-1}\right)$, bilans elektrolitów (DEB) był również wysoki $\left(242-248 \mathrm{mEq} \mathrm{kg}^{-1}\right)$.

U indyków żywionych dietą o niskiej zawartości sodu wykazano znacznie niższy poziom chlorku $(p=0,002)$ i fosforu $(p<0,001)$, a znacznie wyższy poziom magnezu $(p<0,001)$ w surowicy krwi, w porównaniu z innymi grupami. Niewielkie zwiększenie zawartości $\mathrm{Na}$ $\mathrm{w}$ diecie $\left(0,5 \mathrm{~g} \mathrm{~kg}^{-1}\right)$ spowodowało istotny wzrost masy ciała indyków w wieku sześciu tygodni $(p<0,001)$ i poprawę wykorzystania paszy $(p<0,001)$, w porównaniu z dieta bez dodat$\mathrm{ku} \mathrm{Na}$. Nie stwierdzono istotnych różnic w masie ciała i wykorzystaniu paszy u indyków otrzymujacych diety z dodatkiem $\mathrm{NaCl}$. Dodatek $\mathrm{NaCl}$ do diety nie wpłynął na wilgotność ściółki, natomiast występowanie FPD istotnie nasiliło się $\mathrm{w}$ grupach otrzymujących dodatek 1,0 i $2,5 \mathrm{~g} \mathrm{~kg}^{-1} \mathrm{Na}$, w porównaniu z dietą bez dodatku sodu.

Stwierdzono, że umiarkowany dodatek sodu $\left(0,5 \mathrm{~g} \mathrm{~kg}^{-1}\right)$ do diety ubogiej $\mathrm{w}$ ten pierwiastek istotnie zwiększa masę ciała młodych indyków, a nie zwiększa częstości występowania FPD. Dalszy wzrost zawartości sodu w diecie nie zwiększa masy ciała ptaków i wilgotności ściółki, a nasila występowanie FPD.
\end{abstract}

Słowa kluczowe: sód, elektrolity we krwi, wyniki odchowu, indyki.

\section{INTRODUCTION}

The optimization of dietary mineral balance so as to meet the requirements of growing birds is an important consideration in modern intensive poultry farming. The most common reason for insufficient bone mineralization leading to skeletal deformities (including leg bone abnormalities) are mineral metabolism disorders, in particular a deficiency of calcium and phosphorus (RAO et al. 2003, VenäLÄINEN et al. 2006, MAJEWSKA et al. 2009). Leg deformities and abnormalities adversely affect the welfare and growth rate of birds, reduce their activity and decrease feed consumption (NÄ̈̈s et al. 2009). In turkeys, leg problems result for instance from selection for a rapid increase in body weight and breast muscle yield (CRESPO et al. 2000, MiKuLSKI et al. 2009). The fast growth rate of turkeys is often accompanied by nutrient and vitamin D deficiencies (FARUGA et al. 2009, TATARA et al. 2011, ZHоU et al. 2011). 
A high litter moisture content due to nutritional factors may lead to leg diseases, including foot pad dermatitis, in growing birds (FrANCESCH, BRUFAU 2004, MAYNE et al. 2007). The dietary sodium intake is often increased in broilers to stimulate their growth (VIERA et al. 2003, BorGEs et al. 2003, JANKOwski et al. 2011a, b), which results in excess litter wetness. Numerous experiments on chickens have shown that diets with an increased sodium content lead to higher water consumption followed by a higher excreta moisture content (Murakami et al. 2001, Borges et al. 2003, Mushtaq et al. 2007). When compared to chickens, there is a scarcity of data regarding the effects of increased dietary sodium intake in turkeys, with respect to the growth rate of birds, mineral metabolism disorders and incidence of FPD. The above problem is of particular importance in young turkeys fed soybean-based diets rich in potassium. An increased potassium content of feed components increases DEB, also in low-sodium diets (JANKOwSKI et al. 2011a,b), which may have a negative impact on production results in growing turkeys.

The objective of this study was to determine the effect of different inclusion levels of sodium in potassium-rich diets with high DEB on serum macroelement concentrations, growth performance, and incidence of foot pad dermatitis (FPD) in turkeys raised to six weeks of age.

\section{MATERIAL AND METHODS}

The experiment was carried out at the Research Laboratory of the Department of Poultry Science, University of Warmia and Mazury in Olsztyn, on 336 female BUT-10 turkeys kept for six weeks in three-tier battery cages, each with a floor area of $0.5 \mathrm{~m}^{2}$. The turkeys were randomly divided into six groups of eight replicates, each of seven birds. The temperature and lighting program was consistent with the recommendations of the British United Turkeys Ltd. The birds were fed ad libitum and they had free access to water. The composition and nutritional value of low-sodium (without sodium addition) basal diets (1-3 weeks and 4-6 weeks) are presented in Table 1. Basal diets were mixed thoroughly with a premix prepared under laboratory conditions (at a ratio of 99:1), which contained precisely determined amounts of $\mathrm{NaCl}$, so as to increase the sodium content of diets by $0.5,1,1.5,2$ and $2.5 \mathrm{~g} \mathrm{~kg}^{-1}$, relative to the control low-sodium diet. Samples of experimental diets were assayed for the content of sodium and potassium by atomic absorption spectrometry, and chloride - by the biamperometric technique. The analyses were performed at the National Feed Laboratory in Lublin (Poland), and their results were used to calculate the dietary electrolyte balance (DEB), with the following formula: $\mathrm{DEB}=\mathrm{Na}$ $\mathrm{mEq} \mathrm{kg}{ }^{-1}+\mathrm{K} \mathrm{mEq} \mathrm{kg}{ }^{-1}-\mathrm{Cl} \mathrm{mEq} \mathrm{kg}{ }^{-1}$ (Mongin 1981). 
Composition and calculated nutrient content of basal starter (1-3 weeks) and grower (4-6 weeks) diets $(\%)$

\begin{tabular}{|c|c|c|}
\hline Specification & 1 - 3 weeks & 4-6 weeks \\
\hline \multicolumn{3}{|l|}{ Composition (\%): } \\
\hline wheat & 26.22 & 34.47 \\
\hline maize & 20.00 & 18.00 \\
\hline soybean & 41.70 & 36.50 \\
\hline potato protein & 5.00 & 4.45 \\
\hline soybean oil & 2.17 & 2.20 \\
\hline limestone & 1.62 & 1.45 \\
\hline monocalcium phosphate & 2.27 & 2.02 \\
\hline L-Lysine 99 MonohydroCL & 0.28 & 0.25 \\
\hline DL-Methionine 99 & 0.24 & 0.21 \\
\hline Premix $^{1}$ & 0.50 & 0.45 \\
\hline \multicolumn{3}{|l|}{ Nutritional value (calculated): } \\
\hline $\mathrm{ME}\left(\mathrm{kcal} \mathrm{kg}^{-1}\right)$ & 2801 & 2851 \\
\hline crude protein $(\%)$ & 27.99 & 25.98 \\
\hline lysine $(\%)$ & 1.75 & 1.58 \\
\hline methionine $(\%)$ & 0.66 & 0.60 \\
\hline Met + Cys $(\%)$ & 1.10 & 1.02 \\
\hline threonine $(\%)$ & 1.08 & 0.98 \\
\hline tryptophan (\%) & 0.35 & 0.32 \\
\hline $\mathrm{Ca}(\%)$ & 1.26 & 1.12 \\
\hline available P (\%) & 0.65 & 0.60 \\
\hline $\mathrm{Na}(\%)$ & 0.03 & 0.02 \\
\hline
\end{tabular}

${ }^{1}$ Content per kg of premix: vitamin $\mathrm{A}-2400000 \mathrm{IU}$, vitamin $\mathrm{D}_{3}-1000000 \mathrm{IU}$, vitamin $\mathrm{E}$ $-20 \mathrm{~g}$, vitamin $\mathrm{K}_{3}-1.2 \mathrm{~g}$, vitamin $\mathrm{B}_{1}-1 \mathrm{~g}$, vitamin $\mathrm{B}_{2}-1.6 \mathrm{~g}$, vitamin $\mathrm{B}_{6}-1.2 \mathrm{~g}$, vitamin $\mathrm{B}_{12}-6 \mathrm{mg}$, biotin $(\mathrm{H})-60 \mathrm{mg}, \mathrm{Fe}-2 \mathrm{~g}, \mathrm{Mn}-24 \mathrm{~g}, \mathrm{Zn}-22 \mathrm{~g}, \mathrm{Cu}-4 \mathrm{~g}, \mathrm{~J}-600 \mathrm{mg}$, Se $-60 \mathrm{mg}$, panthotenic acid $-5 \mathrm{~g}$, nicotinic acid $-16 \mathrm{~g}$, folic acid $-600 \mathrm{mg}$, choline chloride $-80 \mathrm{~g}$

On day 40, excreta samples were collected underneath the cages in each group, for three hours, to determine the moisture content of droppings. On day 42 , the incidence and severity of foot pad dermatitis (FPD) were assessed based on the scoring system developed by Hocking et al. (2008).

At 42 days, all turkeys were weighed individually and seven birds representing an average body weight of each group were selected for blood sampling from the jugular vein to determine the concentrations of selected ele- 
ments. The analyses were performed by the Analytical Laboratory at the Municipal Hospital in Olsztyn (Poland), using the COBAS INTEGRA 400 PLUS system (Roche, France). The concentrations of $\mathrm{Ca}, \mathrm{P}$ and $\mathrm{Mg}$ were determined by the colorimetric method, and the levels of $\mathrm{Na}, \mathrm{K}$ and $\mathrm{Cl}-$ by indirect potentiometry.

The results were processed statistically by one-way analysis of variance (ANOVA) in an orthogonal design. The significance of differences was estimated by Duncan's test. The calculations were performed using the Statistica software package ver. 8.1.

\section{RESULTS AND DISCUSSION}

The concentrations of sodium, chloride and potassium in experimental diets are shown in Table 2. Our analysis of the sodium content of diets revealed that it corresponded to the assumed dietary sodium levels but differed (lower or higher) from the value of $1.7 \mathrm{~g} \mathrm{~kg}^{-1}$ recommended for the youngest turkeys (NRC 1994). The concentrations of chloride (1.7-5.9 g kg-1) and potassium $\left(11.0 \mathrm{~g} \mathrm{~kg}^{-1}\right)$ in the experimental diets were higher than the respective nutrient requirements of young turkeys, determined at $1.5 \mathrm{~g} \mathrm{~kg}^{-1}$ for $\mathrm{Cl}$ and $7 \mathrm{~g} \mathrm{~kg}^{-1}$ for $\mathrm{K}$ (NRC 1994). DEB was high ( $235-249 \mathrm{mEq} \mathrm{kg}{ }^{-1}$ ), similar to the value recommended for broiler chickens (MoNGIN 1981) and higher than the value of $211 \mathrm{mEq} \mathrm{kg}{ }^{-1}$ recommended for turkeys (NRC 1994). High DEB in poultry diets results from a high potassium content

Table 2

Sodium supplementation, sodium, potassium, chloride content $\left(\mathrm{g} \mathrm{kg}^{-1}\right)$ and dietary electrolyte balance (DEB, $\mathrm{mEq} \mathrm{kg} \mathrm{kg}^{-1}$ ) in experimental diets

\begin{tabular}{|c|c|c|c|c|c|c|}
\hline \multirow[t]{2}{*}{ Content in diet $\left(\mathrm{g} \mathrm{kg}^{-1}\right)$} & \multicolumn{6}{|c|}{$\mathrm{Na}$ addition $\left(\mathrm{g} \mathrm{kg}^{-1}\right)$} \\
\hline & 0 & 0.5 & 1.0 & 1.5 & 2.0 & 2.5 \\
\hline \multicolumn{7}{|l|}{$1-3$ weeks of feeding } \\
\hline $\mathrm{Na}$ & 0.34 & 0.85 & 1.34 & 1.94 & 2.31 & 2.82 \\
\hline $\mathrm{K}$ & \multicolumn{6}{|c|}{11.0} \\
\hline $\mathrm{Cl}$ & 1.7 & 2.7 & 3.2 & 4.3 & 5.2 & 5.9 \\
\hline $\mathrm{DEB}\left(\mathrm{mEq} \mathrm{kg}{ }^{-1}\right)$ & 248 & 242 & 249 & 245 & 235 & 246 \\
\hline \multicolumn{7}{|l|}{ 4-6 weeks of feeding } \\
\hline $\mathrm{Na}$ & 0.31 & 0.78 & 1.21 & 1.75 & 2.08 & 2.72 \\
\hline $\mathrm{K}$ & \multicolumn{6}{|c|}{10.03} \\
\hline $\mathrm{Cl}$ & 1.5 & 2.4 & 2.9 & 3.9 & 4.7 & 5.3 \\
\hline $\mathrm{DEB}\left(\mathrm{mEq} \mathrm{kg}{ }^{-1}\right)$ & 233 & 228 & 234 & 229 & 222 & 238 \\
\hline
\end{tabular}


of cereals and soybean meal, the major feed components (JANKowski et al. 2011a). The potassium content of diets may be reduced by partial replacement of soybean meal with feed components of animal origin, including fish meals (MURAKAMI et al. 2000).

The serum concentrations of macroelements are presented in Table 3 . Turkeys fed the low-sodium diet were characterized by lower sodium concentrations, significantly lower concentrations of chloride $(p=0.002)$ and phosphorus $(p<0.001)$, and significantly higher magnesium levels $(p<0.001)$, compared with the other groups. The only statistically significant difference observed among groups of turkeys fed diets supplemented with $\mathrm{NaCl}$ was lower serum phosphorus concentration in birds receiving 1.0 and $2.5 \mathrm{~g} \mathrm{~kg}^{-1}$

Table 3

Concentrations of selected minerals in blood serum

\begin{tabular}{|c|c|c|c|c|c|c|c|c|}
\hline \multirow{2}{*}{ Mineral element } & \multicolumn{6}{|c|}{$\mathrm{Na}$ addition $\left(\mathrm{g} \mathrm{kg}^{-1}\right)$} & \multirow{2}{*}{ SEM } & \multirow{2}{*}{$p$} \\
\hline & 0 & 0.5 & 1.0 & 1.5 & 2.0 & 2.5 & & \\
\hline $\mathrm{Na}\left(\mathrm{mmol} \mathrm{l} \mathrm{l}^{-1}\right)$ & 141.4 & 149.6 & 148.3 & 149.7 & 145.7 & 147.6 & 1.11 & 0.256 \\
\hline $\mathrm{Cl}\left(\mathrm{mmol} \mathrm{l}^{-1}\right)$ & $104.7^{b}$ & $110.3^{a}$ & $110.1^{a}$ & $109.3^{a}$ & $109.7 \mathrm{a}$ & $109.7 a$ & 0.483 & 0.002 \\
\hline $\mathrm{K}\left(\mathrm{mmol} \mathrm{l} \mathrm{l}^{-1}\right)$ & 3.56 & 3.85 & 3.55 & 3.28 & 2.71 & 3.27 & 0.112 & 0.069 \\
\hline $\mathrm{Ca}\left(\mathrm{mg} \mathrm{dl}^{-1}\right)$ & $13.73^{a}$ & $13.27^{a b}$ & $12.77^{b}$ & $13.31^{a b}$ & $13.29^{a b}$ & $12.94^{b}$ & 0.100 & 0.090 \\
\hline $\mathrm{P}\left(\mathrm{mg} \mathrm{dl}^{-1}\right)$ & $6.3^{c}$ & $9.21^{a}$ & $7.63^{b}$ & $8.56^{a}$ & $8.89^{a}$ & 7.77 & 0.202 & $<0.001$ \\
\hline $\mathrm{Mg}\left(\mathrm{mg} \mathrm{dl}^{-1}\right)$ & $2.83^{a}$ & $2.34^{b}$ & $2.37^{b}$ & 2.37 & 2.41 & 2.46 & 0.035 & $<0.001$ \\
\hline
\end{tabular}

$a, b, c$ - values with different superscript letters within a column are different at $P \leq 0.01$

additional sodium per $\mathrm{kg}$ feed. The results of studies investigating the effects of dietary sodium intake on blood electrolyte levels in chickens are inconclusive: an increased sodium content of diets had no influence on the serum concentrations of sodium and potassium (MUsHTAQ et al. 2005), it had no effect on blood calcium and chloride levels (OLANREWAJU et al. 2007), and it decreased the blood concentrations of sodium and potassium (MUSHTAQ et al. 2007). In an experiment similar to ours (TyKA£OWSKI et al. 2011), a lowsodium diet decreased serum sodium and chloride levels, and increased calcium, magnesium and phosphorus concentrations, compared with chickens fed a sodium-supplemented diet. In the present study, the low-sodium diet surprisingly did not affect the serum $\mathrm{Na}$ concentration but decreased the $\mathrm{Cl}$ level in the serum.

The lowest dietary inclusion of sodium $\left(0.5 \mathrm{~g} \mathrm{~kg}^{-1}\right)$ contributed to a significant increase in the body weights of turkeys at three and six weeks of age $(p<0.001)$, in comparison with the low-sodium diet (Table 4). As a result, feed intake per kg body weight gain during 1-3 and 4-6 weeks was significantly $(P<0.001)$ lower in the group fed a diet with the lowest sodium 
Body weight and feed efficiency ratio in turkeys fed diets with different inclusion levels of sodium

\begin{tabular}{|c|c|c|c|c|c|c|c|c|}
\hline \multirow{2}{*}{ Specification } & \multicolumn{6}{|c|}{$\mathrm{Na}$ addition $\left(\mathrm{g} \mathrm{kg}^{-1}\right)$} & \multirow{2}{*}{ SEM } & \multirow{2}{*}{$p$} \\
\hline & 0 & 0.5 & 1.0 & 1.5 & 2.0 & 2.5 & & \\
\hline \multicolumn{9}{|c|}{ Body weight (g) } \\
\hline 3 weeks & $323^{a}$ & $415^{b}$ & $416^{b}$ & $413^{b}$ & $427^{b}$ & $424^{b}$ & 64 & $<0.001$ \\
\hline 6 weeks & $1055^{a}$ & $1474^{b}$ & $1463^{b}$ & $1478^{b}$ & $1497^{b}$ & $1443^{b}$ & 259 & $<0.001$ \\
\hline \multicolumn{9}{|c|}{ FCR $\left(\mathrm{kg} \mathrm{kg}^{-1}\right)$} \\
\hline 1-3 weeks & $2.09^{a}$ & $1.75^{b}$ & $1.76^{b}$ & $1.81^{b}$ & $1.80 \mathrm{~b}$ & $1.74^{b}$ & 0.027 & $<0.001$ \\
\hline 4-6 weeks & $2.45^{a}$ & $2.02^{b}$ & $2.02^{b}$ & $1.99^{b}$ & $2.03^{b}$ & $2.15^{b}$ & 0.031 & $<0.001$ \\
\hline 1-6 weeks & $2.35^{a}$ & $1.95^{b}$ & $1.97^{b}$ & $1.94^{b}$ & $1.97^{b}$ & $2.04^{b}$ & 0.027 & $<0.001$ \\
\hline
\end{tabular}

$a, b, c$ - values with different superscript letters within a column are different at $P \leq 0.01$

addition, as compared to the group whose diet was not supplemented with $\mathrm{NaCl}$. No significant differences in body weight and feed conversion ratio were found between groups of turkeys fed diets with different $\mathrm{NaCl}$ addition. In many experiments, the growth performance of birds and feed conversion efficiency were improved when the sodium content of feed was increased from 0.0 to $3.0 \mathrm{~g} \mathrm{~kg}^{-1}$ (OvIEDO-RONDON et al. 2001, VIEIRA et al. 2003, Borges et al. 2003, JANKOwski et al. 2011a, b). Such a trend was not observed in our study, in which an increase in the body weights of young turkeys in response to sodium supplementation at $0.5 \mathrm{~g} \mathrm{~kg}^{-1}$ was similar to that noted when sodium addition was two- to five-fold higher.

There were no significant differences in excreta moisture content between turkeys fed diets with different sodium levels (Table 5). Different results were reported for broiler chickens at the final stage of rearing $(\mathrm{MU}-$ RAKAMI et al. 2001, Borges et al. 2003, Mushtaq et al. 2007). It seems that relatively low feed consumption, as compared with the body weights of young turkeys, does not produce the undesirable effect observed in broilers.

Table 5

Dry matter content of excreta (\%) and foot pad dermatitis (FPD) scores in turkeys fed diets with different inclusion levels of sodium

\begin{tabular}{|c|c|c|c|c|c|c|c|c|}
\hline \multirow{2}{*}{ Specification } & \multicolumn{6}{|c|}{$\mathrm{Na}$ addition $\left(\mathrm{g} \mathrm{kg}^{-1}\right)$} & \multirow{2}{*}{ SEM } & \multirow{2}{*}{$p$} \\
\hline & 0 & 0.5 & 1.0 & 1.5 & 2.0 & 2.5 & & \\
\hline DM content & 18.6 & 18.4 & 18.5 & 18.4 & 19.0 & 17.4 & 0.243 & 0.365 \\
\hline FPD & $3.0 \mathrm{c}$ & $3.2 \mathrm{bc}$ & $3.4 \mathrm{~b}$ & $3.5 \mathrm{~b}$ & $3.8 \mathrm{ab}$ & $4.0 \mathrm{a}$ & 0.050 & $<0.001$ \\
\hline
\end{tabular}

$a, b, c$ - values with different superscript letters within a column are different at $P \leq 0.01$ 
The incidence of FPD was the lowest in turkeys fed a NaCl-unsupplemented diet, significantly higher in the groups receiving diets supplemented with sodium at $1.0,1.5$ and $2.0 \mathrm{~g} \mathrm{~kg}^{-1}$, and the highest in turkeys fed a diet with $2.5 \mathrm{~g}$ additional sodium per $\mathrm{kg}$ feed (in the latter case, insignificant only in comparison to the dietary level 2.0). This may suggest that a considerable increase in dietary sodium supply rather excess litter wetness raises the incidence of FPD in growing turkeys. The symptoms of FPD may intensify due to metabolic disorders caused by some diet ingredients, e.g. biogenic amines, and the specific composition of fat (MAYNE 2005).

\section{CONCLUSIONS}

Components of diets fed to young growing turkeys are sodium-deficient, while their potassium content and DEB values exceed the recommended levels. Such diets significantly decrease the concentrations of chloride and phosphorus and increase magnesium levels in the blood serum of turkeys. Moderate sodium supplementation $\left(0.5 \mathrm{~g} \mathrm{~kg}^{-1}\right)$ of a low-sodium diet seems to be enough to increase the body weights of young turkeys, without raising the incidence of FPD. A further increase in the sodium content of the experimental diets did not increase the body weights of birds, but exacerbated the severity of FPD.

\section{REFERENCES}

Borges S.A., Fischer da Silva A. V., Ariki J., Hooge D.M., Cummings K.R. 2003. Dietary electrolyte balance for broiler chickens under moderately high ambient temperatures and relative humidities. Poul. Sci., 82: 301-308.

Crespo R., Stover S.M., Taylor K.T., Chin R.P., Shivaprasad H.L. 2000. Morphometric and mechanical properties of femora in young adult male turkeys with and without femoral fractures. Poult. Sci., 79: 602-608.

Faruga A., Pydynkowska K., Jankowski J., KozŁowski K., PŁudowski P. 2009. Comparison of the effect of cholecalciferol and 25-hydroxycholecalciferol on the characteristic features of femoral and tibia bones in male fattening turkeys. Arch. Geflügelk., 74(4): 237-241.

Francesch M., Brufau J. 2004. Nutritional factors affecting excreta/litter moisture and quality. World's Poult. Sci., J., 60: 64- 75.

Hocking P.M, Mayne R.K., Else R.W., French N.A., Gatcliffe J. 2008. Standard European footpad dermatitis scoring system for use in turkey processing plants. World's Poult. Sci. J., 64(3): 323 - 328.

JANkowski J., ZDUŃcZYK Z., JuśkiEwicz J., KwIEciński P. 2011a. Effect of different dietary sodium levels on the growth performance of broiler chickens, gastrointestinal function, excreta moisture and tibia mineralization. J. Anim. Feed Sci., 20: 93-106.

JANkowski J., Juśkiewicz J., Zduńczyk Z., ŚMiecińskA K., KwiEciński P. 2011b. Effects of the inclusion level and source of dietary sodium from different sodium salts on performance and meat characteristics of broiler chickens. Arch. Anim Nutr., 65(3):186-202. 
Majewska T., Mikulski D., Siwik T. 2009. Silica grit, charcoal and hardwood ash in turkey nutrition. J. Elementol., 14(3): 489-500.

MaYne R.K. 2005. A review of the aetiology and possible causative factors of foot pad dermatitis in growing turkeys and broilers. World's Poult. Sci. J., 61: 256-267.

Mayne R.K., Else R.W., Hocking P.M. 2007. High litter moisture alone is sufficient to cause footpad dermatitis in growing turkeys. Brit. Poult. Sci., 48(5): 538-545.

Mikulski D., Jankowski J., Zduńczyk Z., Wróblewska M., Sartowska K., Majewska T. 2009. The effect of selenium source on performance, carcass traits, oxidative status of the organism, and meat quality of turkeys. J. Anim. Feed Sci., 18: 318-330.

Mongin P. 1981. Recent advantages in dietary anion-cations balance: Applications in poultry. Proc. Nutr. Soc., 40: 285-294.

Murakami A.E., Saleh E.A., Watkins E., Waldroup P.W. 2000. Sodium sources and level in broiler diets with and without high levels of animal protein. J. Appl. Poult. Res., 9: 53-61.

Murakami A. E., Oviedo-Rondon E. O., Martins E. N., Pereira M. S., Scapinello C. 2001. Sodium and chloride requirements of growing broiler chickens (twenty-one to forty-two days of age) fed corn-soybean diets. Poult. Sci., 80: 289-294.

Mushtaq T., Sarwar M., Nawaz H., Aslam M. M., Ahmad T. 2005. Effect and interactions of dietary sodium and chloride on broiler starter performance (hatching to twenty-eight days of age) under subtropical summer conditions. Poult. Sci., 84: 1716-1722.

Musthaq T., Aslam Mirza M., Athar M., Hooge D.M., Ahmad T., Ahmad G., Mushtaq M.M.H., NoReEn U. 2007. Dietary sodium and chloride for twenty-nine to forty-two-day-old broiler chickens at constant electrolyte balance under subtropical summer conditions. Appl. Poult. Res., 16: 161-170.

Nä̈̈s I.A., Paz I.C.L.A., Baracho M.S., Menezes A.G., Bueno L.G.F., Amleida I.C.I., Moura D.J. 2009. Impact of lameness on broiler well-being. J. Appl. Poult. Res., 8: 432-439.

NRC. 1994. Nutrient requirements of poultry. $9^{\text {th }}$ rev. Ed. Ed. National Academy Press, Washington, DC.

Olanrewaju H.A., Thaxton J.P., Dozier W.A., Branton S.L. 2007. Electrolyte diets, stress, and acid-base balance in broiler chickens. Poult. Sci., 86, 1363-1371.

Oviedo-Rondon E. O., Murakami A.E., Furlan A.C., Moreira I., Macari M. 2001. Sodium and chloride requirements of young broiler chickens fed corn-soybean diets (one to twentyone days of age). Poult. Sci., 80: 592-598.

Rao R.S.V., Raju M.V.L.N., Sharma R.P., Nagalakshmi D., Reddy M.R. 2003. Lameness in chickens: alleviation by dietary manipulation. Poult. Intern., 42: 56-61.

Tatara M.R, Krupski W., Jankowski M., ZduńcZyk Z., Jankowski J., Studziński T. 2011. Effects of dietary calcium content and vitamin $D$ source on skeletal properties in growing turkeys. Brit. Poult. Sci., 52(6): 718-729.

TYkąowski B., Stenzel T., Mikulski D., Jankowski J., Zduńczyk Z., Juskiewicz J., Koncicki A. 2011. Level of electrolytes and percentage of T-lymphocyte subpopulations in blond of broiler chickens fed mixtures with different contents of sodium chloride. Bull. Vet. Inst. Pulawy, 55: 333-337.

Venäläinen E., Valaja J., Jalava T. 2006. Effect of dietary metabolisable energy, calcium and phosphorus on bone mineralization, leg weakness and performance of broiler chickens. Brit. Poult. Sci., 47(3): 301-310.

Vieira S.L., Penz A.M., Pophal S., Godoy de Almeida J. 2003. Sodium requirements for the first seven days in broiler chicks. J. Appl. Poult. Res., 12: 362-370.

Zhou Z.L., Rath N.C., Huff G.R., Huff W.E., Rasaputra K.S., Salas C., Coon C.N. 2011. Bone characteristics of 16 wh-old-turkeys subjected to different dietary supplements and stimulated stress. Intern. J. Poult. Sci., 10(5): 332-337. 
